\title{
REFERENCES
}

ALLEN, Betty Molesworth, 1961 Limestone hills near Ipoh. Malayan Nature Journal, Special Issue. p 68-72.

DUNN, Frederick L. 1965 Gua Anak Takun, ecological observations. Malayan Nature Journal 19: 75-87.

HENDERSON M.R. 1939. Flora of the limestone hills of the Malay Peninsula. Journal of the Royal Asiatic Society.

McCLURE, H. Elliott. 1961. Batu Caves, Kuala Lumpur. Malayan Nature Journal, Special Issue. p 73-78.

-, Boo Liat Lim and Sarah E. Winn. 1967 Fauna of the Dark Cave, Batu Caves, Kuala Lumpur, Malay sia. Pacific Insects 9(3): 339-428.

MERTON, Francis. 1962. A visit to Tasek Bera. Malayan Nature Journal 16: $103-110$.

MITCHELL, B.A. 1959. Ecology of tin mine spoil heaps. Malayan Forester 22(2): 111-132.

WEBER, Bruce E. 1968. A national park system for West Malaysia. Federal Game Department. 41pp.

In Oryx, January 1972, Dr Robert Bustard proposed that a national park be created at Trengganu, on Malay sia's west coast, to enclose the laying beaches of the leathery turtle. Mr Weber, and his colleague Dr W.E. Stevens, agree that the leathery turtle's situation calls for immediate conservation action but suggest the area should more appropriately be declared a 'wildlife sanctuary'.

\section{Mammals in Nigeria}

\section{David Happold}

In the article 'New Attitudes in Nigeria', by John Henshaw and Gilbert S. Child (Oryx 11, 4: 275-283) there are some errors which I should like to correct, although lack of information on the distribution of many species makes it difficult to be precise.

Duikers There is confusion between the nomenclature of Maxwell's duiker Cephalophus maxwelli, which occurs in the forest zone of Nigeria west of the Niger river and further west to Senegal, and the blue duiker $C$. monticola, which is supposed to occur east of the Niger river and eastwards into Cameroon and central Africa. If it is shown that maxwelli and monticola are synonomous, there will of course be just one species with a very wide distribution, but until this is resolved it is best to retain the two names. The black duiker $C$. niger was once fairly common in southern Nigeria west of the Niger river, but it is doubtful if it still exists. The yellow-backed duiker $C$. sylvicultor occurs on both sides of the Niger river but is now extremely rare.

Pigs. The red river hog or bush pig, Potamochoerus porcus, is found on both sides of the Niger river. It is not uncommon in the remote forest areas of western Nigeria, and its range extends northwards into the forest relics in the derived savanna.

Primates. The black colobus monkey Colobus polykomos was frequently seen many years ago, but I have not heard of any definite records for several years. As elsewhere in Africa, it has been shot for its skin, and in Nigeria most of the shooting has been done by local Africans with 'Dane' guns. 